Article

\title{
The Phytochemical and Biological Investigation of Jatropha pelargoniifolia Root Native to the Kingdom of Saudi Arabia
}

\author{
Hanan Y. Aati ${ }^{1}$ (D), Ali A. El-Gamal ${ }^{1,2, *}$, Oliver Kayser ${ }^{3}$ (D) and Atallah F. Ahmed ${ }^{1,2}$ (D) \\ 1 Department of Pharmacognosy, Faculty of Pharmacy, King Saud University, P.O. Box 2457, Riyadh 11451, \\ Saudi Arabia; hati@ksu.edu.sa (H.Y.A.); afahmed@ksu.edu.sa (A.F.A.) \\ 2 Department of Pharmacognosy, College of Pharmacy, Mansoura University, El-Mansoura 35516, Egypt \\ 3 Technical Biochemistry, TU Dortmund University, Emil-Figge-Strasse 66, D-44227 Dortmund, Germany; \\ oliver.kayser@tu-dortmund.de \\ * Correspondence: aelgamel@ksu.edu.sa; Tel.: +966-1146-77259
}

Received: 29 May 2018; Accepted: 25 July 2018; Published: 28 July 2018

\begin{abstract}
Extensive phytochemical analysis of different root fractions of Jatropha pelargoniifolia Courb. (Euphorbiaceae) has resulted in the isolation and identification of 22 secondary metabolites. 6-hydroxy-8-methoxycoumarin-7-O- $\beta$-D-glycopyranoside (15) and 2-hydroxymethyl $\mathrm{N}$-methyltryptamine (18) were isolated and identified as new compounds along with the known diterpenoid $(1,3,4$, and 7$)$, triterpenoid ( 2 and 6 ), flavonoid $(5,11,13,14$, and 16), coumarinolignan (8-10), coumarin (15), pyrimidine (12), indole $(17,18)$, and tyramine-derived molecules (19-22). The anti-inflammatory, analgesic, and antipyretic activities were evaluated for fifteen of the adequately available isolated compounds (1-6, 8-11, 13, 14, 16, 21, and 22). Seven $(4,6,10,5,13,16$, and 22) of the tested compounds showed a significant analgesic effect ranging from $40 \%$ to $80 \%$ at $10 \mathrm{mg} / \mathrm{kg}$ in two in vivo models. Compound $\mathbf{1}$ could also prove its analgesic property $(67.21 \%)$ when it was evaluated on a third in vivo model at the same dose. The in vitro anti-inflammatory activity was also recorded where all compounds showed the ability to scavenge nitric oxide (NO) radical in a dose-dependent manner. However, eight compounds $(1,4,5,6,10,13,16$, and 22) out of the fifteen tested compounds exhibited considerable in vivo anti-inflammatory activity which reached $64.91 \%$ for compound 10 at a dose of $10 \mathrm{mg} / \mathrm{kg}$. Moreover, the tested compounds exhibited an antipyretic effect in a yeast-induced hyperthermia in mice. The activity was found to be highly pronounced with compounds $1,5,6,10,13$, and 16 which decreased the rectal temperature to about $37^{\circ} \mathrm{C}$ after $2 \mathrm{~h}$ of the induced hyperthermia $\left(\sim 39^{\circ} \mathrm{C}\right)$ at a dose of $10 \mathrm{mg} / \mathrm{kg}$. This study could provide scientific evidence for the traditional use of J. pelargoniifolia as an anti-inflammatory, analgesic, and antipyretic.
\end{abstract}

Keywords: Jatropha pelargoniifolia; alkaloids; flavonoids; coumarinolignans; diterpenes; anti-inflammatory; analgesic; antipyretic

\section{Introduction}

Euphorbiaceae is considered as one of the largest families of flowering plants which includes approximately 7800 species that are distributed among 300 genera and five subfamilies in tropical and subtropical regions [1,2]. Among the main genera of this family, Jatropha L. is represented by approximately 200 species [2]. Jatropha species are used in folk medicine to treat various diseases, such as skin inflammation, eye infection, chest pain, stomach pain, itching, and as a vermifuge, or as ornamental plants and energy crops in Latin America, Africa, and Asia [3]. J. gossypiifolia, J. elliptica, J. curcas, and J. mollissima, among other species of Jatropha, have been reported for their chemical constituents, biological activities, and medicinal uses [4]. Jatropha glauca, J. curcas, J. spinose, 
and J. pelargoniifolia are the only four species that are distributed in Saudi Arabia and are employed as traditional herbal medicines, owing to their anti-inflammatory, antioxidant, antiseptic, and analgesic properties $[5,6]$.

J. pelargoniifolia Courb. of the current study is grown as a shrub and is widely known as "Obab" in Arabic. It is widely distributed in East Tropical Africa (Sudan, Eritrea, Ethiopia, Somalia, and Kenya) and the Arabian Peninsula (Yemen, Oman, and Saudi Arabia) [7]. The plant is sometimes collected from the wild for local medicinal use, especially the petiole sap which is applied to treat ulcers, severe skin inflammation, and for wound healing [7].

Previous phytochemical studies on the plants belonging to the genus Jatropha revealed a broad range of isolated secondary metabolites, such as diterpenoids, triterpenoids, non-conventional coumarino-lignans, alkaloids, coumarins, flavonoids, cyclic peptides, and steroids [8,9]. However, accordingly reviewed by Zhang et al. [8], the main compounds isolated from Jatropha genus are the terpenoids. J. gossypiifolia was subjected to extensive phytochemical studies that resulted in the isolation of many secondary metabolites, such as propacin, venkatasin, citlalitrione, ricinine, apigenin, jatropholones A\& B, and jatrophone [4]. Moreover, curcusones A-D, taraxerol, nobiletin, curacyclines A \& B, as well uracil, have been isolated from J. curcas. [5,6,8]. Additionally, many reported studies showed the isolation of multidione, multifidone, multifolone, and multifidol glucoside from J. multifida, while from J. podagrica, there was japodic acid, erythrinasinate, $\gamma$-sitosterol, japodagrin, and podacyclines A \& B $[3,8,9]$. This is indeed a reflection of the versatility of the enzymatic system that is present in Euphorbiaceous plants, however nothing was reported regarding J. pelargoniifolia. Thus, it was of interest to explore the active constituents and their biological activity to provide evidence for the traditional use of J. pelargoniifolia.

\section{Result and Discussion}

\subsection{Isolation of Compounds}

The alcoholic extract of J. pelargoniifolia roots powder was successively partitioned with petroleum ether $\left(60^{\circ} \mathrm{C}\right)$, dichloromethane (DCM), ethyl acetate (EtOAc), and then $n$-butanol $(n$-BuOH) to give the correspondent organic fractions. Each fraction was subjected to chromatographic separation on normal and reversed phase (RP) silica gel to yield compounds $1,6,7,10,11$, and 16 from petroleum ether, $\mathrm{DCM}_{2}$, and EtOAc fractions, respectively. Furthermore, the organic extract that was obtained after an acid-base treatment of the roots powder was isolated on a normal silica gel column which was followed by purification on RP-HPLC and/or crystallization to afford compounds 17-22 (Figure 1). 


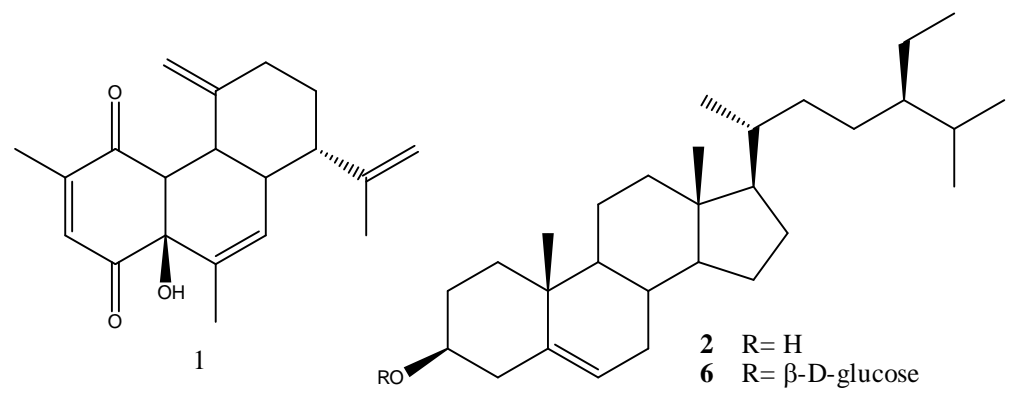

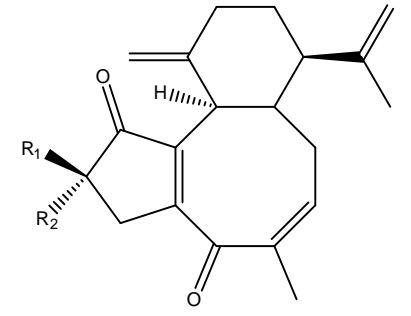

$3 \mathrm{R}_{1}=\mathrm{OH}, \mathrm{R}_{2}=\mathrm{CH}_{3}$

$4 \mathrm{R}_{1}=\mathrm{CH}_{3}, \mathrm{R}_{2}=\mathrm{OH}$<smiles>O=C1CC(c2ccc(O)cc2)Oc2cc(O)cc(O)c21</smiles><smiles>C=Cc1c(C)c(O)cc2c1CCC1C(C)(C)[C@@H](O)CC[C@@]21C</smiles><smiles>[R]O[C@H]1Oc2c(c(OC)cc3ccc(=O)oc23)O[C@H](c2ccc(O)c(OC)c2)[C@@H]1CO</smiles><smiles>O=c1cc(-c2ccc(Br)c(Br)c2)oc2cc(Br)cc(O)c12</smiles>

$11 \mathrm{R}_{1}=\mathrm{H}, \mathrm{R}_{2}=\mathrm{OH}, \mathrm{R}_{3}=\mathrm{OH}$

$13 \mathrm{R}_{1}=\mathrm{OH}, \mathrm{R}_{2}=\mathrm{OH}, \mathrm{R}_{3}=\beta$-D-glucose

$14 \mathrm{R}_{1}=\mathrm{H}, \mathrm{R}_{2}=\mathrm{OCH}_{3}, \mathrm{R}_{3}=$ Rutinose<smiles>O=c1cc[nH]c(=O)[nH]1</smiles>

12<smiles>COc1c(OC2OC(CO)[C@@H](O)[C@H](O)[C@H]2O)c(O)cc2ccc(=O)oc12</smiles>

15<smiles>CCCN(C)CCc1ccc(O)cc1</smiles>

$19 \mathrm{R}_{1}=\mathrm{H}, \quad \mathrm{R}_{2}=\mathrm{CH}_{3}$ $20 \mathrm{R}_{1}=\mathrm{CH}_{3}, \mathrm{R}_{2}=\mathrm{CH}_{3}$

$17 \mathrm{R}=\mathrm{H}$

$18 \mathrm{R}=\mathrm{CH}_{2} \mathrm{OH}$<smiles>CCOc1cc(O)cc2c1C(=O)[C@](O)(Cc1ccc(O)cc1)O2</smiles><smiles>CN(C)CCc1ccc(O)cc1</smiles>

$21 \mathrm{R}_{1}=\mathrm{CH}_{3}, \quad \mathrm{R}_{2}=\mathrm{CH}_{3}$ $22 \mathrm{R}_{1}=\mathrm{H}, \quad \mathrm{R}_{2}=\mathrm{CH}_{3}$

Figure 1. Chemical structures of the compounds isolated from the roots of Jatropha pelargoniifolia.

\subsection{Structure Elucidation}

The new compound 15 was obtained as white crystals. The NMR and ESIMS (Electronspray Ionization Mass Spectrometry) data established the molecular formula of 15 to be $\mathrm{C}_{16} \mathrm{H}_{18} \mathrm{O}_{10}$. The IR absorption bands at max 3349, 1719, and $1625 \mathrm{~cm}^{-1}$ suggested the presence of hydroxyl, ester carbonyl, and aromatic functionalities, respectively. Furthermore, the ${ }^{13} \mathrm{C}$ nuclear magnetic resonance (NMR) 
spectrum of 15 , which was measured in deuterated methanol $\left(\mathrm{CD}_{3} \mathrm{OD}\right.$, displayed sixteen signals of nine $\mathrm{sp}^{2}$ and seven $\mathrm{sp}^{3}$ carbons (including that of a methoxyl group). Its ${ }^{1} \mathrm{H}$ NMR spectrum showed a pair of ortho-coupled protons at $\delta_{\mathrm{H}} 6.26$ and 7.88 (each, $1 \mathrm{H}, \mathrm{d}, J=9.5 \mathrm{~Hz}$ ) as was observed by ${ }^{1} \mathrm{H}-{ }^{1} \mathrm{H}$ correlated spectroscopy (COSY) that was assignable to $\mathrm{H}-3$ and $\mathrm{H}-4$ of an $\alpha$-pyrone ring system of a coumarin, respectively [10]. This was further evidenced from the ${ }^{13} \mathrm{C}$ NMR carbon signals of the -pyrone at $\delta_{C}$ 163.5 (C, C-2), 146.5 (CH, C-4), 144.4 (C, C-8a), 116.2 (CH, C-3), and 112.7 (C, C-4a) (Table 1). Moreover, the single aromatic singlet appearing at $\delta_{\mathrm{H}} 7.00(1 \mathrm{H}, \mathrm{s})$ suggested 15 to be a trisubstituted coumarin. Six proton signals at $\delta_{\mathrm{H}} 3.30-4.99 \mathrm{ppm}$, a doublet of an anomeric proton at $\delta_{\mathrm{H}} 4.99(1 \mathrm{H}, \mathrm{d}, \mathrm{J}=7.8 \mathrm{~Hz})$, and six ${ }^{13} \mathrm{C}$ NMR signals at $\delta_{\mathrm{C}} 106.2\left(\mathrm{CH}, \mathrm{C}-1^{\prime}\right), 75.5\left(\mathrm{CH}, \mathrm{C}-2^{\prime}\right), 77.8\left(\mathrm{CH}, \mathrm{C}-3^{\prime}\right), 71.0\left(\mathrm{CH}, \mathrm{C}-4^{\prime}\right)$, $78.5\left(\mathrm{CH}, \mathrm{C}-5^{\prime}\right)$, and $62.2\left(\mathrm{CH}_{2}, \mathrm{C}-6^{\prime}\right)$ indicated the presence of a $\beta$-D-glucopyranosyl substituent. An aromatic methoxy substituent $\left(\delta_{\mathrm{H}} / \delta_{\mathrm{C}} 3.91 / 57.0\right)$ was also revealed. The ${ }^{3} J_{\mathrm{CH}}$ correlations that were observed in the heteronuclear multiple bond correlation (HMBC) spectrum linked these two substituents to the coumarin carbons at $\delta_{C} 133.2$ and 147.5, respectively (Figure 2). Thus, a hydroxy group should represent the third substituent on the coumarin carbon at $\delta_{\mathrm{C}} 145.7$. The long-range correlations (HMBC) that were found from H-5 $\left(\delta_{\mathrm{H}} 7.00,1 \mathrm{H}, \mathrm{s}\right)$ to the carbons at $\delta_{\mathrm{C}} 146.5(\mathrm{C}-4)$, $145.7, \mathrm{C}-8 \mathrm{a}\left(\delta_{\mathrm{C}} 144.4\right)$, and $\delta_{C} 133.2$ (C-7) indicated that C-8 $\left(\delta_{C} 147.5\right)$ is the position of the methoxyl group. To confirm the locations of the glucosyl and hydroxyl groups, the NMR data of 15 were further compared to those of 5-hydroxy-7-methoxycoumarin-8-O- $\beta$-D-glucoside and other closely related coumarin derivatives that were previously isolated from Daphne pseudo-mezereum [11] and Tetraphis pellucida [12], respectively. The structure of compound $\mathbf{1 5}$ was thus established as a new natural product and was identified as 6-hydroxy-8-methoxy coumarin-7-O- $\beta$-D-glycopyranoside.

Table 1. The ${ }^{1} \mathrm{H}(600 \mathrm{MHz}, \delta$ in $\mathrm{ppm}, J$ in $\mathrm{Hz})$ and ${ }^{13} \mathrm{C}$ NMR $(125 \mathrm{MHz}, \delta$ in ppm) spectral data for compound 15 in deuterated methanol $\left(\mathrm{CD}_{3} \mathrm{OD}\right)$.

\begin{tabular}{ccc}
\hline Position & $\mathcal{\delta}_{\mathbf{H}}$ & $\boldsymbol{\delta}_{\mathbf{C}}$ \\
\hline 2 & - & 163.5 \\
3 & $6.26(\mathrm{~d}, J=9.5 \mathrm{~Hz}, 1 \mathrm{H})$ & 116.2 \\
4 & $7.88(\mathrm{~d}, J=9.5 \mathrm{~Hz}, 1 \mathrm{H})$ & 146.5 \\
5 & $7.00(\mathrm{~s}, 1 \mathrm{H})$ & 106.1 \\
6 & - & 145.7 \\
7 & - & 133.2 \\
8 & - & 147.5 \\
$4 \mathrm{a}$ & - & 112.7 \\
$8 \mathrm{a}$ & - & 144.4 \\
$1^{\prime}$ & $3.99(\mathrm{~d}, J=7.8 \mathrm{~Hz}, 1 \mathrm{H})$ & 106.2 \\
$2^{\prime}$ & $3.46(\mathrm{~d}, J=9.4,9.4,1 \mathrm{H})$ & 75.5 \\
$3^{\prime}$ & $3.47(\mathrm{brs}, 1 \mathrm{H})$ & 77.8 \\
$* 4^{\prime}$ & $3.30(\mathrm{brs}, 1 \mathrm{H})$ & 71.0 \\
$* 5^{\prime}$ & $3.72(\mathrm{~d}, J=4.9,1 \mathrm{H})$ & 78.5 \\
$6^{\prime}$ & $3.80(\mathrm{~d}, J=2.4,1 \mathrm{H})$ & 62.2 \\
$\mathrm{OCH}_{3}-8$ & $3.91(\mathrm{~s}, 3 \mathrm{H})$ & 57.0 \\
$\mathrm{OH}^{\prime} 6$ & 10.53 & - \\
\hline
\end{tabular}

Compound 18 was isolated from the organic extract of the acid-base treated root powder as white needle-shaped crystals. It produced a positive Dragendorff's test, indicating its alkaloid nature. The IR absorption band with a spike at max $3309 \mathrm{~cm}^{-1}$ suggested the presence of hydroxyl and/or secondary amine functionality. The UV absorptions at $\max 295,287,279,230 \mathrm{~nm}$ in MeOH were characteristic to an indole chromophore. The COSY correlations (Figure 2) disclosed the ABCD system of the aromatic protons at $\delta_{\mathrm{H}} 7.41 / 7.00$ (Table 2), which is consistent with 2,3-disubstituted indole alkaloids. A side chain of an ethylene and a $N$-methyl was linked to C-3 of the indole as it was manifested by 2D NMR correlations. However, comparison of ${ }^{1} \mathrm{H}$ NMR data of 18 with those of $N$-methyltryptamine 
(17) revealed that the ${ }^{1} \mathrm{H}$ proton singlet at position 2 in $\mathbf{1 7}$ was replaced in $\mathbf{1 8}$ by a $2 \mathrm{H}$ singlet of a hydroxymethyl proton at $\delta_{\mathrm{H}} 3.91 \mathrm{ppm}$. The ${ }^{13} \mathrm{C}$ NMR spectroscopic and ESIMS data of 18 was thus consistent with a molecular formula $\mathrm{C}_{12} \mathrm{H}_{16} \mathrm{~N}_{2} \mathrm{O}$ of 30 mass units more than that of $17\left(\mathrm{C}_{11} \mathrm{H}_{14} \mathrm{~N}_{2}\right)$. Furthermore, the HMBC correlation that was found from the methylene protons $\left(\delta_{\mathrm{H}} 3.91,2 \mathrm{H}, \mathrm{s}\right)$ to $\mathrm{C}-2$ and C-3 confirmed its C-2 location of the hydroxymethyl group. Finally, a full analysis of th COSY and HMBC spectral correlations (Figure 2) assigned the structure of compound 18 to be 3-(2-(methylamino) ethyl)-1H-indol-2-yl) methanol or 2-hydroxymethyl $N$-methyltryptamine, a new indole alkaloid.

Table 2. The ${ }^{1} \mathrm{H}(700 \mathrm{MHz}, \delta$ in ppm, $J$ in $\mathrm{Hz})$ and ${ }^{13} \mathrm{C}$ NMR $(125 \mathrm{MHz}, \delta$ in ppm) spectral data for compound 18 in deuterated methanol $\left(\mathrm{CD}_{3} \mathrm{OD}\right)$.

\begin{tabular}{ccc}
\hline Position & $\mathcal{\delta}_{\mathbf{H}}$ & $\delta_{\mathbf{C}}$ \\
\hline 2 & - & 128.0 \\
3 & - & 107.2 \\
$3 \mathrm{a}$ & - & 130.6 \\
4 & $7.29(\mathrm{~d}, J=7.8 \mathrm{~Hz}, 1 \mathrm{H})$ & 112.0 \\
5 & $7.00(\mathrm{t}, J=7.8 \mathrm{~Hz}, 1 \mathrm{H})$ & 122.4 \\
6 & $7.41(\mathrm{~d}, J=7.8 \mathrm{~Hz}, 1 \mathrm{H})$ & 120.0 \\
7 & - & 118.6 \\
$7 \mathrm{a}$ & $3.10(\mathrm{t}, J=5.8 \mathrm{~Hz}, 2 \mathrm{H})$ & 138.1 \\
$\alpha \mathrm{CH}_{2}$ & $3.00(\mathrm{t}, J=5.8 \mathrm{~Hz}, 2 \mathrm{H})$ & 54.1 \\
$\beta \mathrm{CH}_{2}$ & $2.69(\mathrm{~s}, 3 \mathrm{H})$ & 21.5 \\
$\mathrm{CH}_{3}$ & $3.91(\mathrm{~s}, 2 \mathrm{H})$ & 44.9 \\
$\mathrm{CH}_{2} \mathrm{OH}$ & & 52.9 \\
\hline
\end{tabular}
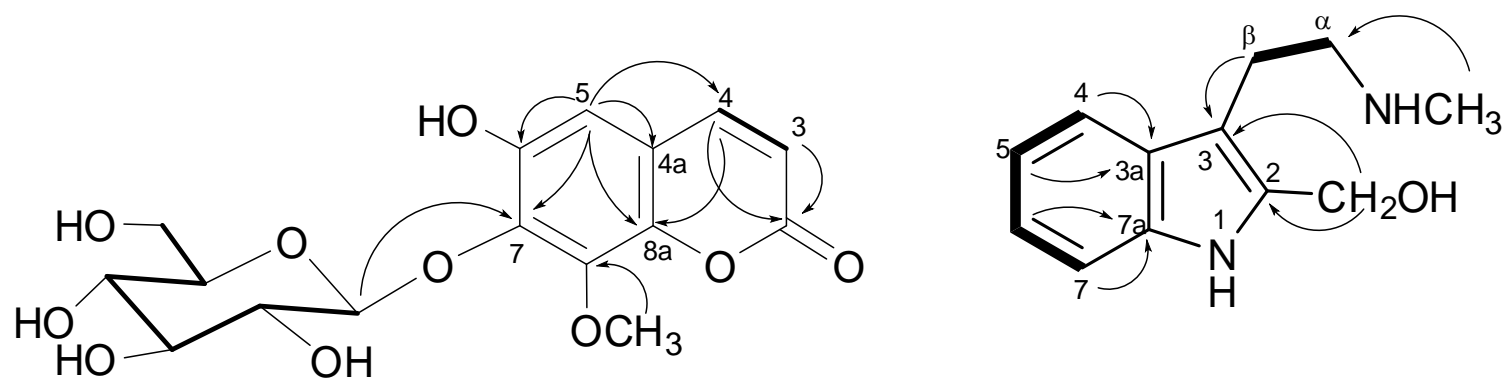

$15 \rightleftharpoons$ COSY correlation

18

Figure 2. Selected heteronuclear multiple bond correlation (HMBC) and correlation spectroscopy (COSY) correlations of compounds 15 and 18.

Compounds 1-14, 16-17 and 19-22, which were also isolated from J. pelargoniifolia roots, were found to be identical to the previously reported natural products by comparison of their spectroscopic (IR, MS, and NMR) data and were identified as jatrophadiketone (1) was isolated from the roots of J. curcas [13], $\beta$-sitosterol (2) isolated from J. curcas seed kernels and from the methanolic extract of the root bark of Calotropis gigantean (Linn.), [14,15], curcuson D (3) and curcuson C (4) were isolated from J. curcas root extract [16], naringenin (5) was isolated from the root extract of J. gossypifolia [17,18], $\beta$-sitosterol glucoside (6) was isolated from the leave and twig extract of J. curcas, [19], spruceanol (7) was isolated from both the aerial extract of J. divaricate and the bark extract of Aleurites moluccana [20,21], propacin (8), cleomiscosin B (9), cleomiscosin A (10) compounds 8 and 10 were isolated from whole plant extracts of J. gossypifolia, while compound 9 was isolated from Mallotus apelta [22-26], apigenin (11) was identified in J. gossypifolia [4,27], uracil (12) was isolated from the leaves of J. curcas [28-30], cynaroside (13) was identified in Scabiosa atropurpurea aerial parts extract [31], linarin (14) was isolated from the extracts of aerial parts of both Bupleurum chinense and Valeriana officinalis [32,33], hovetricoside C (16) was separated from Artocarpus tonkinensis [34], N-methyltryptamine (17) was isolated from 
Zanthoxylum arborescens [35], $N$-methyltyramine (19) was isolated from a beer [36], and hordenine (20) was separated and identified from Ephedra aphylla that was growing in Egypt [37]. Compounds 21 (hordenine $\mathrm{HCl}$ ) and $22(\mathrm{~N}$-methyltyramine $\mathrm{HCl}$ ) were identical to the authentic samples that were purchased from Sigma-Aldrich (St Louis, MO, USA), and on the basis of their ${ }^{1} \mathrm{H}$ NMR and TLC co-chromtographic data, they were isolated previously from Ariocarpus kotschoubeyanus [38].

\subsection{Biological Activity}

The alcoholic extract of J. pelargoniifolia was found to possess significant anti-inflammatory, analgesic, and antipyretic activities when it was tested on in vivo models in a dose-dependent manner [39]. This prompted us to extend the study of these activities on the isolated compounds. The anti-inflammatory, analgesic, antipyretic, and antioxidant activities for the compounds which have been isolated in good yields $(1-6,8-11,13,14,16,21$, and 22) were thus evaluated for their analgesic, anti-inflammatory, antipyretic, and antioxidant activities using in vivo and in vitro models. The analgesic activities were assessed in mice via acetic acid-induced writhing, hot-plate, and tail-flick methods.

In the acetic acid-induced writhing method, compounds 1, 4, 6, 9, 11, 13, 14, 16, and 22 showed a dose-dependent analgesic activity by the reduction in the number of writhings. However, the diterpenoids (1 and 4), $\beta$-sitosterol glucoside (6), flavonoids (5 and 13), and tryptamine $\mathrm{HCl}$ (22) exhibited the strongest analgesic activity by inhibiting writhing in mice (49.07-65.74\% inhibition) at a dose of $10 \mathrm{mg} / \mathrm{kg}$ compared with the standard antinociceptive drug (indomethacin), which showed $72.68 \%$ reduction in the number of writhings at a concentration of $4 \mathrm{mg} / \mathrm{kg}$ (Table S9). The coumarinolignan (8) and hordenine $\mathrm{HCl}$ (21) did not show any inhibition either at 5 or at $10 \mathrm{mg} / \mathrm{kg}$.

In the hot plate method, the thermal responses in the mice that were treated with selected compounds after half, one, and two hours were significantly reduced $(p<0.001)$. Especially in the mice that were treated with a dose $10 \mathrm{mg} / \mathrm{kg}$ of compounds $\mathbf{2 2 , 1 0 , 6 , 4 , 5 , 1 3 , 1 6}$, and $\mathbf{1 4}$, the antinociceptive effects were reduced by $78.57,76.19,74.46,73.33,65.95,59.57,53.48$, and $34.88 \%$, respectively (Table S10). While in the tail-flick method, the tested animals that were treated with $10 \mathrm{mg} / \mathrm{kg}$ of compounds 22, $\mathbf{1}, \mathbf{1 0}, \mathbf{4}, \mathbf{1 3}, \mathbf{1 6}, \mathbf{5}, \mathbf{6}, \mathbf{2 1}, \mathbf{3}$, and $\mathbf{9}$ showed a significant $(p<0.001)$ reduction in antinociceptive activity $(67.32,67.21,60.45,57.59,54.04,53.59,45.58,40.30,21.75,20.39$, and $10.87 \%$, respectively) compared with indomethacin $(95.61 \%)$, as depicted from Table S11. The obtained results confirmed that the strong analgesic activity that is exhibited by the roots of J. pelargoniifolia could be due to its bioactive compounds that may exert their analgesic activities through different CNS (Central Nervous System) mechanisms (peripheral and central). Therefore, further studies with purified compounds should be conducted in the future for further pharmacological and toxicological characterization in order to elucidate the mechanisms that are involved in the central analgesic effect of these compounds.

The anti-inflammatory activities of the major isolated compounds were evaluated by using the carrageenan-induced paw edema model in rats. It was found that the size of the edema was significantly reduced $(p<0.05-0.001)$ in the animals that were treated with the low doses of 5 and $10 \mathrm{mg} / \mathrm{kg}$ compared with the standard anti-inflammatory drug (phenylbutazone) at a high dose of $100 \mathrm{mg} / \mathrm{kg}$. The rats that were treated with compounds 10, 16, 1, 5, 6, 22, 4, 13, 3, 8, 9, 14, and 21 exhibited a significant reduction in their hind paw edema in a dose-dependent manner. Therefore, at a dose of $5 \mathrm{mg} / \mathrm{kg}$, the edema size was reduced by 20.44, 47.23, 17.95, 45.85, 33.97, 44.47, 13.53, 26.51, $7.18,2.20,5.52,6.35$, and 6.35 , respectively, while at $10 \mathrm{mg} / \mathrm{kg}$, the edema size was reduced by 64.91 , $55.24,54.94,51.38,51.10,50.27,49.17,48.61,13.53,12.98,10.22,10.22$, and $8.01 \%$, respectively relative to that reduced by phenylbutazone at $100 \mathrm{mg} / \mathrm{kg}(69.06 \%)$ which was almost similar to that produced by a dose of $10 \mathrm{mg} / \mathrm{kg}$ of compound 10 (64.91\%; Table S12). These anti-inflammatory results were almost compatible with those of the above mentioned antinociceptive activity for the tested compounds.

In addition, the isolated compounds from the J. pelargoniifolia roots were tested for their antipyretic activity against yeast-induced hyperthermia in mice. All tested compounds, which were administered at doses of 5 and $10 \mathrm{mg} / \mathrm{kg}$, showed a considerable reduction in the rectal temperature of the 
hyper-thermic mice, ranging between $36.73 \pm 0.13{ }^{\circ} \mathrm{C}$ and $38.56 \pm 0.16{ }^{\circ} \mathrm{C}$ as compared with the hypothermic effect $\left(36.33 \pm 0.11^{\circ} \mathrm{C}\right.$ ) resulting from indomethacin administration (Table S13). Moreover, compounds $5,6, \mathbf{1 0}, \mathbf{1 3}$, and 16 displayed about a $1^{\circ} \mathrm{C}$ reduction in temperature less than that of the yeast-induced hyperthermia control $\left(\sim 38.8^{\circ} \mathrm{C}\right)$ in the first $30 \mathrm{~min}$. of the experiment.

The percentage inhibition \pm SD of the nitric oxide-scavenging activity was determined for the selected compounds at concentrations of 20,40,60,80, and $100 \mu \mathrm{g} / \mathrm{mL}$, and the obtained results were compared with a standard antioxidant drug (ascorbic acid). Compounds 22, 4, 2, 10, 1, 14, 21, 9, 8, 11, $6,3,13,5$, and 16 exhibited significant free radical-scavenging potency when compared with the free radical-scavenging activity of a strong known antioxidant drug (ascorbic acid) $87.23 \pm 0.98$. The ability of the tested compounds to produce antioxidant effects was found to be concentration-dependent. At a $100 \mu \mathrm{g} / \mathrm{mL}$ dose, the \% inhibition $\pm \mathrm{SD}$ of the tested compounds were $77.60 \pm 4.22,77.36 \pm 4.22$, $76.83 \pm 5.01,75.26 \pm 5.54,71.66 \pm 0.70,70.36 \pm 14.73,67.67 \pm 5.75,63.67 \pm 12.85,63.67 \pm 12.85$, $57.00 \pm 10.21,56.54 \pm 6.03,38.30 \pm 5.63,33.06 \pm 1.86,27.00 \pm 7.85$, and $25.61 \pm 5.18$, respectively (Table S14). The significant antioxidant activity that was associated with the administration of J. pelargoniifolia roots was perhaps due to its content of several phenolic and polyphenolic compounds which play an important role in free radical-scavenging activity with less cytotoxicity.

It is important to mention here that in our previous study, which was carried out on the crude alcoholic extract of J. pelargoniifolia roots, we observed a significant anti-inflammatory activity and analgesic potency [39], likely resulting from the presence of cleomiscosin $A$, hovetricoside $C$, jatrophadiketone, naringenin, $\beta$-sitosterol glucoside, $N$-methyltyramine HCL, curcuson $\mathrm{C}$, cynaroside, curcuson D, propacin, cleomiscosin B, linarin, and hordenine HCL in good yield. Undoubtedly, a synergistic effect between these bioactive constituents produces significant antinociceptive and anti-inflammatory effects. These results justify the use of this plant in folk medicine for the treatment of pain and several inflammatory conditions. Further study will be conducted on the pure isolated compounds to investigate the exact mechanisms underlying their promising biological activities.

Our study proved that J. pelargoniifolia roots can be considered as a source of several biologicallyactive compounds such as hordenine, which exhibited various biological activities like inhibiting melanogenesis in human melanocytes, increasing the respiratory and heart rates [40], the stimulation of gastrin release, inhibition of monoamine oxidase B, and antibacterial properties [41]. Furthermore, Chrisitine et al. reported that $N$-methyltyramine increases blood pressure in an anaesthetized rat, relaxes guinea pig ileum, and increases both the force and the rate of contraction of guinea-pig right atrium by inducing the release of noradrenaline [42]. Additionally, naringenin has been reported to have several pharmacological properties, including anti-dyslipidemic, anti-obesity and antidiabetic, and antifibrotic [43]. Moreover, cleomiscosin A showed strong anti-inflammatory activity and has analgesic and antipyretic potencies [44]. Curcuson $C$ has been reported to have antipyretic activity in vivo [45].

\section{Materials and Methods}

\subsection{Chemicals and Analytical Instruments}

The high-resolution electron spray ionization-mass spectrometry (HRESI-MS) analyses (Bruker, Bremen, Germany) were carried out on an Agilent Triple Quadrupole 6410 QQQ LC-MS mass spectrometer (Central Lab. College of Pharmacy, King Saud University (KSU)). The infra-red spectra were generally recorded in the potassium bromide pellets, unless otherwise specified, using the FTIR spectrophotometer (FT-IR Microscope Transmission, company, Waltham, MA, USA). The melting points were recorded by using a Mettler FP 80 Central Processor that was supplied with a Mettler FP 81 MBC Cell Apparatus. The spectral data for proton and carbon were measured by using Bruker AVANCE 700, 500, and 600 (College of Pharmacy, KSU and Department of Chemistry in TU Dortmund) (Bruker, Fallanden, Switzerland), resonating at either 700, 500, and $600 \mathrm{MHz}$ for proton or at $125 \mathrm{MHz}$ for carbon. The chemical shift values were expressed in ppm with respect to the internal standard 
tetramethyl silane (TMS) or residual solvent peak, and the coupling constants $(J)$ were recorded in Hertz (Hz). The two-dimensional NMR experiments (COSY, HSQC, and HMBC) were performed using the standard Bruker program (Bruker, Fallanden, Switzerland). The silica gel 60/230-400 mesh (Qingdao Oceanic Chemical Co., Qingdao, China), RP C18 silica gel 40-63/230-400 mesh (Merck, Darmstade, Germany), and sephadex LH-20 with particle size 18-111 $\mu \mathrm{m}$ (GE Healthcare, Chicago, IL, USA) were used for column chromatography, while the silica gel and reversed phase 60 F254 (Merck, Germany) were used for thin-layer chromatography (TLC). The detection was achieved by using $10 \% \mathrm{H}_{2} \mathrm{SO}_{4}$ in ethanol or ceric sulfate followed by heating. Alkaloids were tested with Mayer's reagent, Hager's reagent, and Dragendorff's reagent. All of the solvents for analytical purposes (HPLC- and analytical-grade) and the drugs for biological investigation (sodium nitroprusside, sulphanilamide, $\lambda$-carrageenan, acetic acid, ascorbic acid, and phenylbutazone) were procured from Sigma Chemical Company (Sigma-Aldrich, St Louis, MO, USA), and the solvents were distilled prior to use. The preparative and semipreparative Shimadzu HPLC were performed, characterized by Rp-18 (ODS-80 TM, TSK, Tokyo, Japan), $10 \mu \mathrm{m}$ PS, $30 \mathrm{~cm} \mathrm{~L} \times 2.15 \mathrm{~cm}$ i.d. fitted with a guard column $(10 \mu \mathrm{m}$ PS, $7.5 \mathrm{~cm} \mathrm{~L} \times 2.15 \mathrm{~cm}$ i.d.) (ODS-80 TM, TSK, Tokyo, Japan), and VP 250/10 NUCLEODUR C18 HTec, $6 \mu \mathrm{m}$ PS, $25 \mathrm{~cm} \mathrm{~L} \times 2 \mathrm{~cm}$ i.d., respectively which both used a PDA detector.

\subsection{Plant Material}

The roots of J. pelargoniifolia were harvested from Wadi Mojasas, Jazan district (South of Saudi Arabia) in September, 2015. The plant was authenticated by Dr. Jacob Thomas, a botanist of the Science College Herbarium, KSU, where a voucher specimen (\#23064) was deposited.

\subsection{Animals}

Male Wistar rats and white male Swiss albino mice with approximate body weights of $200 \mathrm{~g}$ and $20-25 \mathrm{~g}$, respectively, were divided into groups of six animals. The animals were obtained from the Experimental Animal Care Center, College of Pharmacy, KSU. After a 7-day period in animal accommodation, they were divided into groups and were maintained at $12 \mathrm{~h}: 12 \mathrm{~h}$ light-dark conditions at $55 \%$ humidity. Purina chow rat diet (UAR-Panlab, Barcelona, Spain) and drinking water were supplied to the animals ad libitum. The protocols for the present study were based on the recommendations of the Ethical Committee of the Experimental Animal Care Center of KSU (approval number CPR-7569).

\subsection{Extraction, Fractionation, and Purification}

The air-dried powder of the J. pelargoniifolia roots $(2.5 \mathrm{~kg})$ was divided into two parts-A and $\mathrm{B}$-and $2.5 \mathrm{~kg}$ of part A was subjected to solvent extraction, while the remaining $500 \mathrm{~g}$ of the root powder (part B) was exposed to the acid-base treatment. Part A was extracted by maceration with $80 \%$ ethanol $(3 \mathrm{~L} \times 5)$ for three successive days. This process was repeated until complete exhaustion of the plant material [46]. The alcoholic extract was then concentrated to dryness under reduced pressure at $40{ }^{\circ} \mathrm{C}$ using a rotary evaporator to give $270 \mathrm{~g}$ of the dried alcoholic extract. The dried alcoholic extract was suspended in $\mathrm{H}_{2} \mathrm{O}$ and was successively partitioned with petroleum ether, dichloromethane, ethyl acetate, and $n$-butanol $(600-700 \mathrm{~mL} \times 3)$ of each to obtain $13.3,10.3,5.1$, and $33.6 \mathrm{~g}$, respectively.

A part of the petroleum ether fraction $(12.8 \mathrm{~g})$ was chromatographed over silica gel CC (Column Chromatography) using a gradient of petroleum ether/EtOAc followed by methanol $(\mathrm{MeOH})$. The $100 \mathrm{~mL}$ fractions of each were collected and screened by TLC, and similar fractions were combined together to give six fractions (A-F). Fraction A which was eluted by $15 \%$ EtOAc in petroleum ether $(609.8 \mathrm{mg}$ ) was further subjected to $\mathrm{CC}$ and was eluted by petroleum ether/acetone gradient elution, sub fraction A1 $(188.9 \mathrm{mg})$ which was eluted by $6 \%$ acetone in petroleum ether was further purified by preparative HPLC gradient elution using acetonitrile: $\mathrm{H}_{2} \mathrm{O}$ : TFA) to yield $25.0 \mathrm{mg}$ of compound 1. Direct crystallization of fraction B, which was eluted by $20 \%$ EtOAc in petroleum ether, yielded $302.7 \mathrm{mg}$ of compound 2. Fractions $\mathrm{C}$ and D which were eluted with 30 and $40 \%$ EtOAc in 
petroleum ether, respectively, were crystallized with acetone to yield compounds 3 and 4 (14.3 and $25.4 \mathrm{mg}$, respectively). Additionally, fraction E (287.3 mg) which was eluted by $50 \%$ EtOAc was also crystallized from acetone to give $20.2 \mathrm{mg}$ of compound 5, while fraction F which was eluted with $40 \%$ $\mathrm{MeOH}$ in EtOAc yielded $330.4 \mathrm{mg}$ of compound 6, which was purified by crystallization with acetone.

The dichloromethane (DCM) fraction (9.8 g) was subjected to silica gel CC using a column that was packed by the wet method with petroleum ether. The polarity of the column was gradually increased by treating it with DCM, followed by MeOH to give 142 fractions, and similar fractions were pooled together depending on their TLC similarity. Fraction 48-64 which was eluted by $10 \%$ $\mathrm{MeOH}$ in DCM was concentrated (4.6 g) and was then subjected to repeated silica gel CC, followed by a preparative revered phase TLC using $\mathrm{MeOH}: \mathrm{H}_{2} \mathrm{O}(3: 1)$ as a solvent system, leading to the isolation of white crystals of compound $7(7.5 \mathrm{mg})$. Moreover, subtractions that were obtained using $90 \%$ acetone in petroleum ether, $100 \%$ acetone, and $10 \%$ acetone in $\mathrm{MeOH}$, followed by crystallization with $\mathrm{MeOH}$, afforded compounds 8 (15.1 mg), 9 (15.9 mg), and 10 (16.4 mg), respectively.

The EtOAC extract $(4.6 \mathrm{~g})$ was subjected to silica gel CC using a gradient of DCM/MeOH to give six fractions (I-IV). Fractions I which were eluted with $84 \%$ DCM afforded $17 \mathrm{mg}$ of compound $\mathbf{1 1}$ after crystallization with MeOH. Fractions II which were eluted with 70\% DCM afforded $8.6 \mathrm{mg}$ of compound 12. The fractions that were eluted with $35 \%$ and $40 \% \mathrm{MeOH}$ in DCM (II and IV) were further purified by repeated acetone crystallization to give 14.9 and $13.2 \mathrm{mg}$ of compounds 13 and 14, respectively. Fractions $\mathrm{V}$ which were eluted with $45 \% \mathrm{MeOH}$ were further subjected to $\mathrm{CC}$ using $\mathrm{DCM} / \mathrm{MeOH}$, followed by a semi-preparative HPLC (Rp-18) using MeOH:H $\mathrm{H}_{2} \mathrm{O}$ :TFA as a solvent system afforded $8.6 \mathrm{mg}$ white crystals of compound 15. Finally, fractions VI which were eluted with 50\% MeOH in DCM were subjected to further purification over sephadex LH-20 (using water and methanol as an eluent in the gradient mode). The subfraction VI-A, which was eluted by $20 \%$ $\mathrm{H}_{2} \mathrm{O} / \mathrm{MeOH}$ was further purified over a reversed-phase column to give $12 \mathrm{mg}$ of compound 16.

Furthermore, Part B was subjected to an acid-base treatment according to the Stas-Otto method I which was described by Mandhumitha and Fowsiya [47]. The crude alkaloidal fraction was subjected to silica columns using gradient elution with solvent system DCM/MeOH: $\mathrm{NH}_{4} \mathrm{OH}$, resulting in five fractions. The first fraction which was eluted using $17 \% \mathrm{MeOH}$ in DCM with an addition of $1 \% \mathrm{NH}_{4} \mathrm{OH}$ was followed by further purification by reversed-phase semipreparative HPLC using MeOH:H $2 \mathrm{O}: \mathrm{TFA}$ to give compound 17 (6.3 mg). The second fraction which was separated by 20\% $\mathrm{MeOH}$ in DCM to afford a subfraction, which was further purified by a semipreparative HPLC gradient elution using MeOH: $\mathrm{H}_{2} \mathrm{O}$ :TFA as a solvent system, afforded white needle crystals of compound 18 (9.4 mg). The third and fourth fractions which were eluted by $23 \%$ and $26 \% \mathrm{MeOH}$ in DCM, followed by an addition of a few drops of $\mathrm{NH}_{4} \mathrm{OH}$, afforded 6.8 and $8.8 \mathrm{mg}$ of compounds 19 and 20, respectively. The fifth fraction was eluted by $60 \% \mathrm{MeOH}$ in $\mathrm{DCM}$ with an addition of a few $\mathrm{NH}_{4} \mathrm{OH}$ drops to yield $86.7 \mathrm{mg}$ of a mixture of two compounds, which were subjected to further purification using the reversed-phase semipreparative HPLC in gradient mode with $\mathrm{MeOH}: \mathrm{H}_{2} \mathrm{O}$ :TFA as the mobile phase, resulting in the production of the white crystals of compounds 21 and 22 (20.3 and $21.5 \mathrm{mg}$ ), respectively.

6-hydroxy-8-methoxycoumarin-7-O- $\beta$-D-glycopyranoside (compound 15): White crystals; m.p. 219-220 ${ }^{\circ} \mathrm{C}$; UV (MeOH) $\lambda_{\max } \operatorname{nm} 325$ and 250; IR (KBr) vmax $\left(\mathrm{cm}^{-1}\right): 3349,1719,1625,1520,1465$, 829; ${ }^{1} \mathrm{H}$ NMR, ${ }^{13} \mathrm{C}$ NMR, and HMBC data, see Table 1 and Figure 2; HRESIMS (positive) $m / z 371.0900$ $[\mathrm{M}+\mathrm{H}]^{+}$(calculated for $\mathrm{C}_{16} \mathrm{H}_{18} \mathrm{O}_{10}, 371.097825$ ).

3-(2-(methylamino)ethyl)-1H-indol-2-yl)methanol (compound 18): White needle crystals; m.p. 179-189 ${ }^{\circ} \mathrm{C}$; UV (MeOH) $\lambda_{\max } \mathrm{nm}: 295,287,279,230 ; \mathrm{IR}(\mathrm{KBr}) \nu_{\max }\left(\mathrm{cm}^{-1}\right): 3309,1140,1120,1105,1011$, 855. ${ }^{1} \mathrm{H}$ NMR, ${ }^{13} \mathrm{C}$ NMR, and HMBC data, see Table 2 and Figure 2; HRESIMS (positive) $m / z 205.1293$ $[\mathrm{M}+\mathrm{H}]^{+}$(calculated for $\mathrm{C}_{12} \mathrm{H}_{16} \mathrm{~N}_{2} \mathrm{O}, 205.134088$ ). 


\subsection{Antinociceptive Activity Test}

\subsubsection{Hot-plate Method}

The hot-plate method that was described by Turner was used to determine the antinociceptive activity of the compounds that were isolated from the J. pelargoniifolia root [48].

\subsubsection{Acetic Acid-induced Writhing in Mice Test}

The method of Koster et al. was used to evaluate the analgesic effect of the pure compounds that were isolated from the J. pelargoniifolia root [49].

\subsubsection{Tail-Flick Method}

Acute nociception was induced using the tail-flick apparatus (Tail flick Apparatus Harvard), following the method that was recommended by D'amour and Smith [50].

\subsection{Anti-Inflammatory Activity Test}

Carrageenan-Induced Edema in the Rat Paw Method

The method that was described by Winter et al. was used to evaluate the anti-inflammatory potency of the isolated compounds [51].

\subsection{Antipyretic Activity Screening}

Yeast-Induced Hyperthermia in Rats

Hyperthermia was induced in the mice followed by the administration of the isolated compounds, and their hypothermic activity was determined by applying the method described by Loux [52].

\subsection{Antioxidant Effect}

Nitric Oxide Radical-Scavenging Assay

This assay was carried out according to the procedure that was described by Green et al. [53].

\subsection{Statistical Analysis}

The values in the tables are given as mean $\pm \mathrm{SE}$. The data were analyzed by using one-way analysis of variance (ANOVA) followed by the Student's t-test. Values with $p<0.05$ were considered significant.

\section{Conclusions}

The wide traditional use of Jatropha species as anti-inflammatory and analgesics has prompted us to investigate the chemistry and bioactivity of J. pelargoniifolia growing in Saudi Arabia. The phytochemical study of the plant roots resulted in the isolation of six terpenoids, five flavonoids, three coumarinolignans, two tryptamines, and two tyramines (including their $\mathrm{HCl}$ salts), a coumarin, and a pyrimidine. The new compounds were identified as 6-hydroxy-8-methoxy coumarin-7-O- $\beta$-D-glycopyranoside and 2-hydroxymethyl- $N$-methyltryptamine. To the best of our knowledge, hovetricoside $\mathrm{C}$ and $\mathrm{N}$-methyltryptamine were isolated herein from the Euphorbiaceae family for the first time, while cleomiscosin $\mathrm{B}$, hordenine, and $\mathrm{N}$-methyltyramine with their salts, cynaroside, and linarin were characterized in the Jatropha species for the first time.

On the basis of the significant anti-inflammatory, analgesic, antipyretic, and antioxidant activities that were observed in the experimental animals for the alcoholic extract of J. pelargoniifolia, fifteen of the adequately isolated compounds were consequently biologically evaluated. Eleven of these compounds exhibited strong analgesic activity. Twelve out of the fifteen compounds succeeded to reduce the chemically-induced inflammatory marker in the animals in a dose-dependent manner. 
Moreover, five of the compounds demonstrated an anti-pyretic effect by a reduction about a $1{ }^{\circ} \mathrm{C}$ in an induced hyperthermia model. The isolated compounds also exhibited varying degrees of nitric oxide-scavenging activity. The significant antioxidant activity that was associated with the administration the extract of J. pelargoniifolia roots was thus perhaps due to its phenolic content such as flavonoid, coumarins, and coumarinolignans. The synergistic effect between these bioactive constituents might explain the significant antinociceptive and anti-inflammatory effect of the alcoholic extract of J. pelargoniifolia roots and may scientifically justify the use of this plant in folk medicine for the treatment of pain and several inflammatory conditions.

Supplementary Materials: The following are available online. Figures S1-S4: ${ }^{1} \mathrm{H}-,{ }^{13} \mathrm{C}-\mathrm{NMR}, \mathrm{COSY}$ and $\mathrm{HMBC}$ spectra of compound 15, Figures S5-S8: ${ }^{1} \mathrm{H}-,{ }^{13} \mathrm{C}-\mathrm{NMR}, \mathrm{HMBC}$ and HSQC spectra of compound 18, Tables S9-S11: Analgesic effect of isolated compounds by using acetic acid-induced writhing, hot plate and tail flick methods in mice, Table S12: Effect of isolated compounds on carrageenan-induced paw edema in albino rats, Table S13: Effect of isolated compounds on yeast-induced hyperthermia in mice, Table S14: \% Inhibition of nitric oxide scavenging activity for isolated compounds at different concentrations.

Author Contributions: H.Y.A., A.E.-G., and O.K. conceived and designed the experiments; H.Y.A. performed the experiments; H.Y.A., A.E.-G. analyzed the data; H.Y.A. contributed reagents/materials/analysis tools; H.Y.A. wrote the paper; A.E.-G. participated in the experiments' design and coordination and helped to draft the manuscript; O.K. participated in the experiment design and supervised. A.F.A. contributed to the structure elucidation of some of the compounds and to the partial writing of the manuscript.

Funding: The Deanship of Scientific Research at King Saud University, Project no. RG-1437-021.

Acknowledgments: The authors extend their appreciation to the Deanship of Scientific Research at King Saud University for funding the work through the Research Group, Project no. RG-1437-021.

Conflicts of Interest: The authors declare no conflict of interest.

\section{Appendix A}

Supplementary data associated with ${ }^{1} \mathrm{H}$ NMR, ${ }^{13} \mathrm{C}$ NMR, COSY, and HMBC of compounds 15 and 18 are available in Supplementary Information. In addition, Tables for all of the biological test results are provided.

\section{References}

1. Alves, M.V. Checklist das espècies de Euphorbiaceae Juss. Ocorrentes no semi-áridopernambucano, Brasil. Acta Bot. Bras. 1998, 12, 485-495. [CrossRef]

2. Webster, G.L. Classification of the Euphorbiaceae. Ann. Mo. Bot. Gard. 1994, 81, 3-143. [CrossRef]

3. Sabandar, C.W.; Ahmat, N.; Jaafar, F.M.; Sahidin, I. Medicinal property, phytochemistry and pharmacology of several Jatropha species (Euphorbiaceae): A review. Phytochemistry 2013, 85, 7-29. [CrossRef] [PubMed]

4. Félix-Silva, J.; Giordani, R.B.; Silva, A.A., Jr.; Zucolotto, S.M.; Fernandes-Pedrosa, M.F. Jatropha gossypiifolia L. (Euphorbiaceae): A review of traditional uses, phytochemistry, pharmacology, and toxicology of this medicinal plant. Evid-Based Complement. Altern. Med. 2014, 2014, 1-32.

5. Oskoueian, E.N.; Saad, W.Z.; Omar, A.; Ahmad, S.; Kuan, W.B.; Zolkifli, N.A.; Hendra, R.; Ho, Y.W. Antioxidant, anti-inflammatory and anticancer activities of methanolic extracts from Jatropha curcas Linn. J. Med. Plants Res. 2011, 5, 49-57.

6. Yusuf, S.O.; Maxwell, I.E. Analgesic activity of the methanolic leaf extract of Jatropha Curcas (Linn). Afr. J. Biomed. Res. 2010, 13, 149-152.

7. Schmelzer, G.H.; Fakim, G.A. Jatropha pelargoniifolia; Record from Prota4u; PROTA (Plant Resources of Tropical Africa/RessourcesVégétales de l'AfriqueTropicale): Wageningen, The Netherlands, 2007.

8. Zhang, X.P.; Zhang, M.L.; Sua, X.H.; Huoa, C.H.; Gub, Y.C.; Shi, Q.W. Chemical constituents of the plants from genus Jatropha. Chem. Biodivers. 2009, 6, 2166-2183. [CrossRef] [PubMed]

9. Zhu, J.Y.; Zhang, C.Y.; Dai, J.J.; Rahman, K.; Zhang, H. Diterpenoids with thioredoxin reductase inhibitory activities from Jatropha multifida. Nat. Prod. Res. 2017, 31, 2753-2758. [CrossRef] [PubMed]

10. Zhao, A.; Yang, X.Y. New coumarin glucopyranosides from roots of Angelica dahurica. Chin. Herb. Med. 2018, 10, 103-106. [CrossRef] 
11. Konishi, T.; Wada, S.; Kiyosawa, S. Constituents of the leaves of Daphne pseudo-mezereum. Yakugaku Zasshi: J. Pharm. Soc. Jpn. 1993, 113, 670-675. [CrossRef]

12. Jung, M.; Geiger, H.; Zinsmeister, H.D. Tri- and tetrahydroxycoumarin derivatives from Tetraphis pellucida. Phytochemistry 1995, 39, 379-381. [CrossRef]

13. Liu, J.Q.; Yang, Y.F.; Wang, C.F.; Li, Y.; Qiu, M.H. Three new diterpenes from Jatropha curcas. Tetrahedron 2012, 68, 972-976. [CrossRef]

14. Habib, M.R.; Nikkon, F.; Rahman, M.; Haque, M.E.; Karim, M.R. Isolation of stigmasterol and $\beta$-sitosterol from methanolic extract of root bark of Calotropis gigantean (Linn). Pak. J. Biol. Sci. 2007, 10, 4174-4176. [PubMed]

15. Oskoueian, E.; Abdullah, N.; Ahmad, S.; Saad, W.Z.; Omar, A.; Ho, Y.W. Bioactive compounds and biological activities of Jatropha curcas L. kernel meal extract. Int. J. Mol. Sci. 2011, 12, 5955-5970. [CrossRef] [PubMed]

16. Naengchomnong, W.; Thebtaranonth, Y. Isolation and structure determination of four novel diterpenes from Jatropha curcus. Tetrahedron Lett. 1986, 27, 2439-2442. [CrossRef]

17. Maltese, F.; Erkelens, C.; Kooy, F.V.D.; Choi, Y.H. Identification of natural epimeric flavanone glycosides by NMR spectroscopy. Food Chem. 2009, 116, 575-579. [CrossRef]

18. Mutheeswarana, S.; Saravana, P.; Kumarb, P.; Yuvaraj, V.; Duraipandiy, N.A.; Balakrishnab, K.; Ignacimuthu, S. Screening of some medicinal plants for anticariogenic activity: An investigation on bioactive constituents from Jatropha gossypifolia (L.) root. Biocatal. Agric. Biotech. 2017, 10, 161-166. [CrossRef]

19. Hufford, C.D.; Oguntimein, B.O. Non-polar constituents of Jatropha curcas. Lloydia 1978, 41, 161-165.

20. Denton, W.R.; Harding, W.W.; Anderson, C.I.; Jacobs, H.; McLean, S.; Reynolds, W.F. New diterpenes from Jatropha divaricata. J. Nat. Prod. 2001, 64, 829-831. [CrossRef] [PubMed]

21. Alimboyoguen, A.B.; De Castro-Cruz, K.A.; Shen, C.C.; Li, W.T.; Ragasa, C.Y. Chemical constituents of the bark of Aleurites moluccana L. Willd. J. Chem. Pharm. Res. 2014, 6, 1318-1320.

22. Akbar, E.; Sadiq, Z. Coumarinolignoid rare natural product: A review. Asian J. Chem. 2012, 24, 4831-4842.

23. Begum, S.A.; Sahai, M.; Ray, A.B. Non-conventional lignans: coumarinolignans, flavonolignans, and stilbenolignans. Prog. Chem. Org. Nat. Prod. 2010, 93, 1-70.

24. Das, B.; Venkataiah, B. A minor coumarino-lignoid from Jatropha gossypifolia. Biochem. Syst. Ecol. 2001, 2, 213-214. [CrossRef]

25. Biswanath, D.; Kashinatham, A.; Venkataiah, B.; Srinivas, K.V.N.S.; Mahender, G.; Reddy, M.R. Cleomiscosin A, a coumarino-lignoid from Jatropha gossypifolia. Biochem. Syst. Ecol. 2003, 31, 1189-1191.

26. Xu, J.F.; Feng, Z.M.; L, J.; Zhang, P.C. New hepatoprotective coumarinolignoids from Mallotus apelta. Chem. Biodivers. 2008, 5, 591-597. [CrossRef] [PubMed]

27. Lee, D.G.; Mok, S.Y.; Choi, C.; Cho, E.J.; Kim, H.Y.; Lee, S. Analysis of apigenin in Blumea balsamifera Linn DC. and its inhibitory activity against aldose reductase in rat lens. J. Agric. Chem. Environ. 2012, 1, 28-33.

28. Abdelgadir, H.A.; Staden, J.V. Ethnobotany, ethnopharmacology and toxicity of Jatropha curcas L. (Euphorbiaceae): A review. S. Afr. J. Bot. 2013, 88, 204-218. [CrossRef]

29. Hurd, R.E.; Reid, B.R. NMR spectroscopy of the ring nitrogen protons of uracil and substituted uracils; relevance to a base pairing in the solution structure of transfer RNA. Nucleic Acids Res. 1977, 4, 2747-2756. [CrossRef] [PubMed]

30. Staubmann, R.; Schubert-Zsilavecz, M.; Hiermann, A.; Kartnig, T. A complex of 5-hydroxypyrrolidin-2-one and pyrimidine-2,4-dione isolated from Jatropha curcas. Phytochemistry 1999, 50, 337-338. [CrossRef]

31. Elhawary, S.S.; Eltantawy, M.E.; Sleem, A.A.; Abdallah, H.M.; Mohamed, N.M. Investigation of phenolic content and biological activities of Scabiosa atropurpurea L. World Appl. Sci. J. 2011, 3, 311-317.

32. Zhang, T.; Zhou, J.; Wang, Q. Flavonoids from aerial part of Bupleurum chinense DC. Biochem. Syst. Ecol. 2007, 35, 801-804. [CrossRef]

33. Fernández, S.; Wasowski, C.; Paladini, A.C.; Marder, M. Sedative and sleep-enhancing properties of linarin, a flavonoid-isolated from Valeriana officinalis. Pharmacol. Biochem. Behav. 2004, 77, 399-404. [CrossRef] [PubMed]

34. Thuy, T.T.; Kamperdick, C.; Ninh, P.T.; Lien, T.P.; Thao, T.T.P.; Sung, T.V. Immunosuppressive auronol glycosides from Artocarpus tonkinensis. Pharmazie 2004, 59, 297-300. [CrossRef] [PubMed]

35. Grina, J.A.; Ratcliff, M.R.; Stermitz, F.R. Old and new alkaloids from Zanthoxylum arborescens. J. Org. Chem. 1982, 47, 2648-2651. [CrossRef] 
36. Yokoo, Y.; Kohda, H.; Kusumoto, A.; Naoki, H.; Matsumoto, N.; Amachi, T.; Suwa, Y.; Fukazawa, H.; Ishida, H.; Tsuji, K.; et al. Isolation from beer and structural determination of a potent stimulant of gastrin release. Alcohol Alcohol. 1999, 34, 161-168. [CrossRef] [PubMed]

37. Abdel-Kader, M.S.; Kassem, F.F.; Abdallah, R.M. Two alkaloids from Ephedra aphylla growing in Egypt. Nat. Prod. Sci. 2003, 9, 1-4.

38. Neal, J.M.; Sato, P.T.; Johnson, C.L.; McLaughlin, J.L. Cactus alkaloids X: Isolation of hordenine and $N$-methyltyramine from Ariocarpus kotschoubeyanus. J. Pharm. Sci. 1971, 60, 477-478. [CrossRef] [PubMed]

39. Hanan, A.; Ali, E.-G.; Oliver, K. A comparative study of the biological activities of Jatropha pelargoniifolia and Jatropha glauca native to Saudi Arabia. Phytomedicine 2018, submitted.

40. Fana, Y.; Li, X.; Zhang, L.; Duana, P.; Li, F.; Zhao, D.; Wang, Y.; Wub, H. Ether-functionalized ionic liquids: Highly efficient extractants for hordenine. Chem. Eng. Res. Des. 2017, 124, 66-73. [CrossRef]

41. Ma, J.; Wang, S.; Huang, X.; Geng, P.; Wen, C.; Zhou, Y.; Yu, L.; Wang, X. Validated UPLC-MS/MS method for determination of hordenine in rat plasma and its application to pharmacokinetic study. J. Pharm. Biomed. Anal. 2015, 111, 131-137. [CrossRef] [PubMed]

42. Christine, S.; Bell, A.; Stewart-Johnsox, E. N-methyltyramine, a biologically active amine in Acacia seeds. Phytochemistry 1979, 18, 2022-2023.

43. Jadeja, R.N.; Devkar, R.V. Polyphenols and flavonoids in controlling non-alcoholic steatohepatitis. In Polyphenols in Human Health and Disease, 1st ed.; Watson, R.R., Preedy, V.R., Zibadi, S., Eds.; Academic Press: San Diego, CA, USA, 2014; pp. 615-623.

44. Begum, S.; Saxena, B.; Goyal, M.; Ranjan, R.; Joshi, V. B.; Rao, V.; Krishnamurthy, S.; Sahai, M. Study of anti-inflammatory, analgesic and antipyretic activities of seeds of Hyoscyamusniger and isolation of a new coumarinolignan. Fitoterapia 2010, 81, 178-184. [CrossRef] [PubMed]

45. Picha, P.; Naengchomnong, W.; Promratanapongse, P.; Kano, E.; Hayashi, S.; Ohtsubo, T.; Zhang, S.W.; Shioura, H.; Kitai, R.; Matsumoto, H.; et al. Effect of natural pure compounds curcusones A and C from tropical herbal plant Jatropha curcas on thermo sensitivity and development of thermotolerance in Chinese hamster V-79 cells in vitro. J. Exp. Clin. Cancer Res. 1996, 15, 177-183.

46. Skoog, D.; Holler, F.J.; Nieman, T.A. An introduction to chromatographic separations. In Principles of instrumental analysis, 5th ed.; Skoog, D., Holler, F.J., Nieman, T.A., Eds.; Saunders College Publishing: Philadelphia, PA, USA, 1992; pp. 674-700.

47. Madhumitha, G.; Fowsiya, J. A. Hand Book on: Semi Micro Technique for Extraction of Alkaloids; International E-Publication: Indore, India, 2015; p. 9.

48. Turner, R.A. Analgesics, in Screening Methods in Pharmacology; Academic Press: London, UK, 1965; p. 100.

49. Koster, R.; Anderson, M.; De Beer, E.J. Acetic acid for analgesic screening. Fed. Proc. 1959, 18, $412-417$.

50. D'amour, F.E.; Smith, D.L. A method for determining loss of pain sensation. J. Pharmacol. Exp. Ther. 1941, 72, 74-79.

51. Winter, C.A.; Risley, E.A.; Nuss, G.W. Carregeenan-induced oedema in hind paw of the rats as an assay for anti-inflammatory drugs. Exp. Biol. Med. 1962, 111, 544-547. [CrossRef]

52. Loux, J.J.; Depalma, D.D.; Yankell, S.L. Antipyretic testing of aspirin in rats. Toxicol. Appl. Pharmacol. 1972, 22, 672-675. [CrossRef]

53. Green, L.C.; Wagner, D.A.; Glogowski, J.; Skipper, P.L.; Wishnok, J.S.; Tannenbaum, S.R. Analysis of nitrate, nitrite, and [15N] nitrate in biological fluids. Anal. Biochem. 1982, 126, 131-138. [CrossRef]

Sample Availability: Samples of the compounds 1-22 are available from the authors. 